\title{
Senior High Schools Teachers' Perception of Integrating ICT into Social Studies Lessons in the New Juaben Municipality
}

\author{
Eric Gyasi Mensah ${ }^{1}$, Shani Osman ${ }^{2 *}$ \\ ${ }^{1}$ Department of Social Studies, Ofori Panin SHS, Post Office Box 11, Kukurantumi, Ghana \\ ${ }^{2}$ Department of Social Sciences, Tumu College of Education, Post Office Box 19, Tumu, Ghana \\ E-mail: shaniosman@yahoo.com
}

Received: 24 July 2021; Revised: 22 November 2021; Accepted: 17 January 2022

\begin{abstract}
This study employed a descriptive survey design to survey all 107 social studies teachers' perception of integrating Information and Communication Technologies (ICT) into the teaching and learning of social studies using a questionnaire in the public senior high school in the New Juaben Municipality. The results revealed that the teachers had a positive perception that incorporating ICT into the Social Studies classroom makes lessons more engaging, varied, and well-presented, as well as allows the teacher to control the instructional time effectively, aids students in comprehending what they have been taught, makes lessons more concrete, and increases students' attention in class. The findings also showed that ICT tools like computers, internet systems, educational software, printers and overhead projectors were found to be limited in the schools. Significant differences in perception were found among teachers based on age, gender and teaching experience. Multiple regression analysis found that age was a predictor of perceptions of the integration of ICT. It was, therefore, recommended that heads of schools should enable teachers to utilize ICT facilities appropriately in Social Studies lessons. Also, the Ministry of Education should set aside funds each year to retain, replace, and extend ICT infrastructure in schools. Moreover, the Ministry of Education should review the policy of the non-use of mobile phones by senior high students.
\end{abstract}

Keywords: information communication technology (ICT), benefits, perception, social studies, teacher demographic characteristics

\section{Introduction}

In many fields, including education, the term Information Communication Technology (ICT) has remained an indispensable element. This is because, in several countries, ICT has become the highway for knowledge transfer. Certainly, the role of ICT is clear in learning not only in social science learning but also in science (Abdullahi, 2014). Moreover, educational institutions are also including ICT in their general management (Rodríguez-Rodríguez \& HerasGonzález, 2020). Grabe and Grabe (2007) argued that technology integration has now passed through innovation and has transformed organizations and societies that have completely changed people's way of thinking, working and living. As a matter of urgency, schools and other educational establishments are incorporating ICT into the curriculum to train and groom students to survive in "a knowledge society" (Ghavifekr et al., 2012).

Copyright (C2022 Shani Osman, et al.

DOI: https://doi.org/10.37256/ser.3120221053

This is an open-access article distributed under a CC BY license

(Creative Commons Attribution 4.0 International License)

https://creativecommons.org/licenses/by/4.0/ 
According to the United Nations Development Programme (UNDP) (2006), ICT encompasses the entire spectrum of electronic technology and methods used to manage information and knowledge. It is an undeniable fact that the rate at which ICT evolves, as well as its effect on socio-economic activities, cannot be ignored. ICT has become a key element in generating wealth worldwide, having been incorporated into nearly every aspect of the trade, government, and civic life in developed countries. This integration has undeniably rejuvenated all facets of life, as well as had a ripple impact on education.

Valuing the success of emerging technologies at workplaces and in daily life, educational establishments are attempting to rebuild their instructional and educational systems, as well as classroom settings, to ensure the closure of the technological gap between advanced and less economic countries in the teacher-learner activities. This restructuring process aims to develop learners' knowledge and comprehension of specific subject areas, as well as their ability to learn meaningfully and increase their professional productivity (Tomei, 2005).

ICT incorporation in education generally enhances and brings to life the essence of education as learners are made to learn focusing on concrete materials as against learning in the abstract. Because learners who are used to technology are more than certainly to learn in a technologically driven world, the case of ICT incorporation in educational settings, especially in classroom practices, is critical. This is as a result of the assistance of ICT elements and components, the utilization of technology in education helps to advance pedagogical approaches that can contribute to better learning and teaching (Jamieson-Proctor et al., 2006). It is reasonable to believe that technology-based resources and equipment will improve the instruction of virtually all subjects, including languages, science, mathematics, humanities, arts and other major disciplines. Jorge et al. (2003) believe that ICT offers support and additional resources for both educators and students, promoting constructive learning by using computers as learning tools.

The ability to improve upon pedagogical methods in teaching, to improve understanding and better classroom interaction to enhance quality classroom delivery and also to access quality education thereby improving the management of educational systems is one of the advantages of ICT integration into education (World Bank, 2012). Integrating ICT lessons denotes the process of being able to select the appropriate ICT available that best suits a class, and how to use it appropriately to ensure it fits into the lesson delivery to ensure better understanding (Ifegbo, 2005). The Integration of ICT into education demands that the teacher above all should have in-depth knowledge and understanding of the available ICTs and the expertise in utilizing them, so as to successfully incorporate them into the teaching and learning, for maximum lesson delivery. The teacher is expected to integrate ICT to achieve the specified objectives, through the use of appropriate ICT materials and methods to ensure better lesson delivery.

Several studies support the notion that ICT is critical for learners to learn and work in this era of information technology. Yelland (2001) supports this notion that traditional classroom learning is not effective in the preparation and training of the learner to operate or be useful in the workplace of modern society. Furthermore, research by Dede (1998) posits that there is an improvement in memory retention, an increase in understanding of lessons taught, and an increase in self-motivation when ICT is integrated into the lesson delivery. ICT integration is also effective when dealing with large class sizes, as it promotes easier group learning, role-playing, group discussions and group projects (Forcheri \& Molfino, 2000). Teachers contribute significantly to the management of learning, and they should be equipped with skills in ICT to create fresh learning experiences employing the latest cutting-edge educational technology. According to Sugar et al. (2004), teachers' expectations and attitudes to ICT incorporation are motivated by personal beliefs about the reasons for adoption. Teachers' optimistic views about ICT incorporation in education are amongst the most important factors for the effective implementation of ICT in their lessons. This informs them of the right choice of technological tool to employ in the teaching and learning segment (Gulbahar \& Guven, 2008). Hong (2014) posited that the essence of instructors for ICT incorporation is vital and cannot be overlooked, as they act as gatekeepers. Thus, teachers' views and attitudes toward ICT influence students' perceptions of ICT usage.

Teachers play a critical role in classroom interaction and their perceptions influence what and how they teach. The integration of ICT into the teaching-learning activities is heavily affected by teachers' beliefs, which are an important factor in defining their pedagogical activities (Baylor \& Ritchie cited in Miima et al., 2013). Gulbahar and Guven (2008) support this claim, claiming that teachers' perceptions and attitudes of new technology are significant predictors of its use in the classroom. The extent to which a technology is utilized is influenced by the perceptions users have for it, regardless of how successful it is (Huang \& Liaw, 2005). As a result, incorporating technology into the classroom is unlikely to succeed until teachers agree to use it and stick to doing so (Zhao \& Cziko, 2001). 
The teacher's responsibility as the gatekeeper of classroom change is to ensure that learners are ready for a digital world by incorporating ICTs into classroom practices (Dawson et al., 2000). One of the errors made in the incorporation of ICTs in education, according to Meyer et al. (1999), was concentrating on students first, instead of teachers. If teachers are hesitant and unaccustomed to incorporate technology in their classes, it is doubtful that it could be done so successfully. As a result, it is important to consider teachers' perspectives on technology adoption, not forgetting their successes and challenges in incorporating ICTs in their classrooms (Becker, 1994).

According to Bordoh et al. (2018), social studies is an integrated field with many concepts that demands a resourceful instructor to teach it. This is because social studies is considered to be a multidisciplinary subject that draws its contents from history, economics, geography, sociology, political science, anthropology, philosophy, religion, archaeology, law and other humanities and natural sciences (Aggarwal, 2001; Martorella, 1985; National Council for the Social Studies, 1994). Berson (1996) posits that Social Studies is designed to produce productive people who are capable of rational thought and decision-making in a democratic society.

ICT is not as widely used in social studies classrooms as it is in other subjects, hence, Martorella (1997) referred to ICT incorporation in Social Studies as a "sleeping giant". This is worrying because among other subjects, Social Studies is certainly the ideal subject to integrate ICT (Martorella, 1997). According to Bolick et al. (2007), the rate of ICT integration into Social Studies has been slower than in other subject areas, which is a sad trend.

The application of ICT to boost Ghana's socioeconomic growth is highlighted in the country's national development strategy (Government of Ghana, 2003). An ICT national commission was established in 2002 to develop a national ICT policy in order to achieve this national aim. The Ghana ICT for Accelerated Development Policy (ICT4AD) is the product of this commission's report (Government of Ghana, 2004). The ICT4AD policy statement served as a blueprint for Ghana's information society and economic growth. It stressed the importance of laying the groundwork for the country's socioeconomic growth in the new technological age. Promoting, developing, and exploiting the potential of ICT in the educational sector, especially in classrooms, was one of the fourteen (14) defined pillars of the ICT4AD policy. As a result, policymakers have begun to pay attention to ICT inclusion in education in the last decade. The application of ICT at all levels of the educational system for teaching and learning was mandated by the ICT in Education Policy. This was shown by Ghana's decision to make ICT a compulsory subject in primary and secondary schools. There has been the provision of laptop computers to most senior high schools under the program One Laptop per Child (OLPC), all in the view of meeting the challenges and demands of globalization. In Ghana, it has been observed most senior high schools and some primary schools have well-equipped computer labs. The Ghana Government and other non-governmental organizations have also made an huge investment in the provision of ICT to educational institutions with the objective of enhancing the value of education and also preparing the learner for the new informative and technological world.

ICT integration into educational institutions in Ghanaian schools has generally increased and is in the ascendancy in recent years. However, while lots of research has brought to light knowledge about the availability and use of ICT in schools, there is not much information about how ICT is integrated into teaching and learning. Adubifa (2001) supports the essence of appraising the status and usage of ICT when he posits that "each institution must be able to assess its current situation with regard to the capacity to use ICT in teaching and learning, research outreach and professional services, as well as to achieve administrative efficiency" (p. 6).

\subsection{Statement of the problem}

Ghana's government has made significant investments in ICT to educational organizations and institutions, from the basic level up to the university level during the last decade. There has been the provision of logistics and infrastructure, particularly, at the colleges of education and universities (Ministry of Education, 2008). The aim is to prepare technologically skilled graduate teachers who can incorporate ICT in their teaching. Despite the fact that 87 percent of Ghana's second-cycle institutions are well-equipped with ICT facilities (Ministry of Education, 2008), Anderson and Becker (1994) found that teachers of Social Studies are not integrating ICT into their lessons as intended. According to a study conducted by Boakye and Banini (2008), 71 percent of Ghanaian teachers (including those teaching Social Studies) never utilize a computer in the classroom. This indicates that teachers have not adequately explored ICT's potential in the Social Studies classroom.

Several Social Studies educationalists argue that integrating ICT into the classroom will encourage better 
understanding and enhance the teaching and learning of the subject, but they are sleeping because there has been little ICT study, growth, and implementation among Social Studies educators (Ehman \& Glenn, 1991). Despite the capacity of ICT for training, practice and explorative practices, social studies education teachers seem not to have been able to incorporate ICT into their curricula and teaching. According to Anderson and Becker (1994), social studies and mathematics teachers were among the least likely to use ICT (12 percent and 11 percent, respectively) and engage students in higher-order thought practices. Given the low rate of ICT use in the Social Studies curriculum, it is essential to appraise the status of ICT integration into Social Studies lessons in senior high schools in the New Juaben Municipality by exploring the perception of Social Studies teachers of integrating ICT in the classroom, and the degree of the availability of ICT tools in schools.

\subsection{Research questions}

The study is guided by the following research questions.

1. What are the perceptions of Social Studies teachers towards ICT integration into the teaching and learning of Social Studies in senior high schools in the New Juaben Municipality?

2. What ICT tools are available in the senior high schools in the New Juaben Municipality used in teaching and learning Social Studies?

3. Are there any significant differences between teachers' background characteristics (gender, age, academic qualification, teaching experience and training in ICT) and perceptions of the integration of ICT into teaching and learning of Social Studies?

4. What is the impact of the background characteristics of teachers on perceptions of the ICT integration into teaching and learning of Social Studies?

\section{Literature review}

\subsection{Benefits of ICT in education}

The world is gradually being transformed into an informative and smaller community with the help of ICT. This transformation, therefore, requires educators to try and inject ICT into their daily endeavors in order to promote the teaching and learning efficiency. This is evident in the recent rise in the use of ICT in many educational institutions because of its significance in education. Fan and Ho (2012) describe three significant academic applications of ICT. ICT's primary role is to use ICT software to improve teaching and learning. The second objective is to promote other teaching roles, such as marking and student record management in schools to monitor the academic experience and progress of learners. ICT's third position in education is to develop students' data literacy. According to Osin (1998), the usage of computers in lessons has enabled what he refers to as "individualized interactivity", where students are provided information and presentations tailored to their requirements and tastes. Teachers and students would benefit from the infusion of information and communication technology systems. This will aid the enhancement and increase the standard of education by providing educational aid for subject areas that are challenging. Teachers need to be active in collaborative projects to achieve these goals and design methods for action improvement, including using ICT collaborations as a resource. According to Zhao and Cziko (2001), three requirements are needed to incorporate ICT by teachers in their classrooms: Teachers should have faith in the efficacy of ICT, believe that using ICT will not cause disruption, and have faith in themselves that they have control over the ICT. Smeets (2005) notes that the majority of educators never take benefit of ICT's potential to improve the efficiency of learning environments, despite the fact that they strongly support this capability.

In three lower primary and senior secondary schools, Harris (2002) published case studies on innovative ICTrelated pedagogical methods. According to Harris (2002), the significance of ICT is accomplished when dedicated educators are able to look for modern approaches to improve classroom strategies employing ICT. As a response, not only will the use of ICT boost learning environments, but it will also help educate the next generation for their future lives and jobs (Wheeler, 2001). Changing teacher demographics can result in new tasks and key competencies for potential teaching positions that require high ICT standards and are more participative than lecture-based teaching 
positions (Littlejohn, et al., 2002). Educational institutions can provide online access to learning resources by using specialized websites at any time. Students are not even required to be physically present in some educational institutions. Virtual classrooms have grown in popularity as internet connectivity has increased. In such virtual classrooms, the significant obstacles of distance and time are made almost outmoded (Stennes, 2008). A further benefit of using ICT in education is that communication among teachers, teachers and students, and students and students are enriched and cooperation between them is strengthened, thus moving farther away from the previous teaching approach of "banking" in which information is only transferred from teachers to students with no room for critical thinking (Hawkins, 2002).

According to Jacobson and Levin (1993), teachers were certain that use of the software will aid learners in their learning, and they accepted that using electronic mail for research and correspondence, for example, can save time for teachers and students. Balanskat et al. (2007) note that the most improvement has been accomplished in recent years and that increased exposure and integration have enhanced educators' positive attitudes toward ICT. ICT is increasingly being used by teachers to help them properly prepare for their work and save time. The success in which ICT is integrated into the classroom determines the benefits of its use (Condie \& Munro, 2007). According to Dawes (2001), ICT has the potential to help to teach across the curriculum by offering creative ways to communicate effectively. The capacity of ICT in education to alter how individuals learn is undeniable.

UNESCO (2007) claims that incorporating ICT into education systems has the capacity to improve the educational quality and promote greater access by disadvantaged groups and communities to knowledge and services. Therefore, ICT could be used effectively:

1. Make education simpler, less expensive and safe of range limitations.

2. The consequence of improvements in teaching and learning is better academic success.

According to Segers and Verhoeven (2002), the use of machines can contribute to successful improvements in literacy. Also, learners with learning disabilities can be inspired and involved by using ICT.

\subsection{Teachers'perception of the integration of ICT into teaching}

Teachers' views of ICT are critical because they influence the use of ICT in lessons whether positively or negatively. Teachers' perceptions have been identified as a key factor in educators' ICT preparedness to incorporate technology in classroom instruction.

In Ghana, the use of ICT in schools has long been recognized as a means of modernizing the educational process, and it has been greeted with great enthusiasm (Mfum-mensah, 2003). Incorporating ICT into senior high schools' curricula has a favorable influence on both students' and instructors' knowledge and abilities (Pittard et al., 2003). The perceived advantages of integrating ICT into education might be judged by both students' and instructors' pedagogical expertise (British Educational Communications and Technology Agency (BECTA), 2004). For example, in a study of students from a few Hong Kong schools, the researchers discovered that the positive outcome of using ICT in instructional approaches was the validation it offered instructors and students. As a result, teachers all around the world continue to value the incorporation of ICT into education (Law et al., 2002). Gragert (2000) claimed that employing ICT-related gadgets and computer-based knowledge acquisition made students at second-cycle colleges more willing to learn. The teachers agreed that incorporating ICT lessons boosted students' engagement in the educational process.

Schulz-Zander et al. (2002) investigated student collaboration and found that students tend to help one other with technical challenges that come from the usage of ICT, therefore, operating as an intellectual discourse community and cooperating in collaborative affiliations with various schools. Thus, ICT-integrated teaching and learning increases academic curiosity and provides a sense of pleasure, shifting students from the static role of knowledge recipients to the dynamic one of information producers (Haddad \& Drexler, 2002). In contrast, Hennessy et al. (2005) in an empirical investigation found that there was anticipated tension with the introduction of ICT into the education system, and this reflected the external circumstances of conventional tests. The conditions required to incorporate ICT into education in order to improve teaching and learning were judged difficult. For example, during examinations, the use of ICT devices was prohibited, resulting in a drop in motivation among educators and students who used ICT for teaching and learning (Hennessy et al., 2005).

Eugene (2006) employed an observation approach to look into educators' expectations and perceptions of using ICT in the classroom. According to the findings, there was a contradiction between educators' expectations and perceptions of ICT's use in the classroom. Another research, conducted by Simonson (2004), looked at the opinions of 
high school instructors and found a link between educators' perceptions and their usage of ICT in the classroom. Drent and Meelissen (2008) backed up Simonson's (2004) claim, citing a survey of 210 instructors that found a link between teachers' technology use and favorable attitudes about the use of ICTs and innovative use of ICTs in the classroom. In a parallel study comprising six (6) European Union nations, Huang and Liaw (2005) found that teachers' perceptions of ICT use have a positive impact on their identification of the benefits of ICT and its usage in education. Rozell and Gardner (1999) discovered a link between teachers' ICT knowledge experience and their perceptions of integration of ICT in the classroom.

Buabeng-Andoh (2012) states that in Ghana, researches on teachers' perceptions on the use of ICT in education in secondary schools are inadequate as contrasted to developed countries. Buabeng-Andoh (2012) investigated teachers' perceptions of ICT use for teaching and learning, as well as their perceived abilities to do so. According to the findings, a higher number of research participants strongly believed that ICT can promote students' engagement in the educational process, facilitate assessment, and student participation. The results also found a positive correlation between competences and ICT and concluded that educators' capability and confidence were pointers to using ICT in teaching and learning.

Sim and Lau (2014) did a study in Malaysia on teachers' perceptions on the usage of ICT as a math and science instructional method. Educators were polled about how they felt about the utilization of ICT in their lessons. The study used a survey tool to gather basic data on existing ICT usage in high school math and science classes, and also to explore teachers' needs for ICT preparation and support. The findings revealed that the vast majority of those who responded agreed that using ICT makes their teaching more successful $(75 \%)$ and more coordinated $(80 \%)$, depend less on textbooks (37\%) and is more capable of satisfying students' diverse demands (48\%). Although 39.2 percent of respondents accepted that increased ICT usage necessitates a longer time for teaching, 43.4 percent were of the view that technology allows them to relinquish so much instructional control. In general, respondents accepted that their lesson plans were getting richer (55\%) and that as a result of their internet and technology use, they are changing their methods of arranging classroom activities (56\%). Another encouraging sign is that $85 \%$ of them said that they would like more ICT applications to be included in their lessons. The use of ICT applications helps teachers promote learning more efficiently and boost students' comprehension of concepts, resulting in increased knowledge and better exam results.

Hong (2016) conducted interviews with 23 social studies teachers in Colorado to report on their opinions, experiences, and attitudes toward ICT integration in lessons. According to the findings of the study, the majority of the teachers had good attitudes regarding ICT as an instructional tool and desired to learn more about it so that they could utilize it effectively in the classroom. They did, however, identify a key hurdle to their use of ICT in the classroom as the lack of availability of ICT.

Amengor (2011) conducted research in Ghana on history teachers' perceptions of ICT in the promotion of learning and teaching in Kumasi and the Cape Coast Metropolis. A descriptive research design was used for this study with a census survey of 78 history teachers. The questionnaire was employed in collecting data for analysis. According to the survey, 95.6 percent of respondents believe that ICT improves teaching effectiveness, 80.6 percent believe that ICT helps meet students' diverse needs, and 85.1 percent believe that ICT enhances their efficiency. The findings clearly indicate that respondents had a positive perception of ICT. Also, in Ghana, Buabeng-Andoh (2012) investigated 231 second-cycle teachers' perceptions, skills, and practices of ICT in their lessons. The teachers were chosen from 14 schools using a simple random sampling technique. Results showed that most teachers felt that ICT can give them the opportunity to access educational materials through the internet to supplement the content of the course and can also enhance educational processes. Most teachers agreed or strongly agreed that ICT will improve the commitment and feedback of students ( 90.9 percent) and boost co-operation between pupils (90.4 percent). However, the perception that ICT would boost students' language writing skills ( 76.2 percent) was the lowest. On the whole, teachers' attitudes regarding the use of ICT in the classroom were generally favorable.

In the West Mamprusi Municipality, Bariham et al. (2019) did a study on incorporating computer-based instruction into Social Studies lessons by basic school teachers. According to the findings, teachers' attitudes toward the use of Computer Based Instructions (CBIs) as instruments for teaching, and learning Social Studies were found to be good. But, due to low ICT skills of teachers, scarcity of technological infrastructure, absence of internet, inadequate time, unreliable power supply absence of technical assistance for educators, and the absence of school-based ICT policy, 
teachers did not integrate CBI into their instructions. Variables of teachers such as experience, gender, age and location have been found to be significant in terms of how well CBI is integrated into the instructional processes.

\subsection{Relationship between perceptions and teachers'demographic characteristics}

Several studies have shown that there is a relationship between teachers' demographic profile, such as age, teaching experience, ICT training, qualification, and gender and their perceptions about the usage of ICT in classrooms (Mahdum, et al., 2019; Padmavathi, 2013; Semerci \& Aydin, 2018). Teaching experience, according to Bingimlas (2009), is largely defined as the number of years a teacher has been in the classroom, which may influence his or her capacity to integrate ICT into the pedagogical practice. A major teacher-related impediment to ICT integration is a lack of teaching expertise. The lack of experience of a teacher poses a significant obstacle to the employment of computers in teaching methods and practices. Tezci (2009) claims that if teachers have a lot of experience, there will be more ICT use in the classroom. According to Pelgrum and Law (2001), the primary barrier to ICT adoption in education is a lack of technical knowledge among teachers in poor countries.

A study by Kumar et al. (2008) proposed that age is a crucial determinant in the adoption of ICT. Young (2000) claims that younger and less experienced teachers utilize computers more than older instructors because they are more likely to be computer literate, have had more technologically rich teacher training, and are less likely to be constrained by prior habits, views, or attitudes. According to Cavas et al. (2009), there is a link between instructor age and computer attitudes. Another study by Korte and Husing (2007) found that younger instructors are less skeptical about the benefits of ICT in the classroom. Despite this, a large body of study evidence firmly suggests that age has no influence on teachers' usage of ICT (Al-Senaidi et al. 2009; Sim \& Lau, 2014).

Another factor that may influence teachers' perceptions of the use of ICT in the classrooms is the extent of previous ICT experience they have had in their carrier. Poor earlier ICT experience among teachers may certainly be viewed as a very substantial impediment to ICT integration in the classroom. According to Drent and Meelissen (2008), establishing strong experience with ICT and changes connected to ICT facilitates the development of learner-centered educational practice. Mahdum et al. (2019) found that the teachers have a positive perception towards ICT integration in their classroom. However, Mahdum et al. (2019) discovered that ICT training and teacher perceptions have no statistically significant link.

Padmavathi (2013) conducted a survey among secondary school teachers in the Indian state of Puducherry. Teachers' attitudes about computer use were found to be positive. Teachers' attitudes on computer use were unaffected by their age, gender, computer training, or teaching subject. However, age, gender, computer ownership, teaching subject, instructors' competency, and training appear to have a substantial impact on actual computer use by teachers. The study also found that the key predictors of ICT integration in school education are home access to computers, skill training, and teacher competency.

Semerci and Aydin (2018) explored the views of high school teachers in Ankara concerning the employment of ICT in the classroom. They found that teachers have a good attitude toward using ICT in their classrooms. They also found that there was no significant difference in ICT willingness among teachers based on gender, age, teaching experience, ICT experience, ICT skills, or the amount of ICT training they have had. However, their ICT experience, ICT skills, and the quantity of previous ICT training have a substantial impact on their unfavorable attitude (ICT anxiety) regarding the ICT use in education.

\subsection{Availability of information computer technology tools for teaching and learning}

In Ghana, pre-service teachers face challenges in incorporating ICTs into their lesson plan and delivery due to the unavailability of ICT tools, despite their best efforts to incorporate ICTs into their teaching whenever possible (Akaadom, 2019). Adebi-Caesar (2012) conducted a descriptive study in the Lower Manya Krobo District involving 154 teachers to determine the state of ICT in secondary schools. The questionnaire was utilized in the data collection. Teachers were asked about the degree to which ICT resources and facilities were available in their classrooms. According to the survey, $97.9 \%$ of the teachers reported having inadequate computers and equipment, with just 2.1 percent claiming to have enough computers. When asked if they utilize computers in the classroom, 90.7 percent said they never do, while 9.3 percent said they do. This clearly demonstrates that none of the schools studied have enough computers for students to use. 
Research on Internet use in senior high schools in the Cape Coast Metropolis in Ghana's Central Region was conducted by Ayebi-Arthur et al. (2009). The results established that the majority of the teachers had internet access. Also,70 percent of the students had internet access. This indicates that the majority of students and teachers have internet access. Agyei and Voogt (2011) investigated the state of ICT usage in mathematics lessons in SHS. The participants of the study included 60 in-service and 120 pre-service teachers. Data was collected via interviews and questionnaires. Approximately 98 percent of in-service teachers from the 16 SHS said their schools had at least one computer lab. The Parents-Teachers Association (PTA), according to some teachers, was influential in bringing computers into their classrooms. Further inquiries were made to assess the computers' accessibility. Data access (office/ computer lab) was $21 \%$, computer access (staff meeting room/Library) was $13 \%$, and internet accessibility was $46 \%$, indicating that computer resources were not readily accessible. The teachers went on to claim that ICT labs were only used for mandatory information technology (IT) courses, making personal or other use of the facilities difficult.

A study conducted in Zambia by Chirwa and Mubita (2021) employed a descriptive study design, using observations and in-depth interviews. A homogeneous purposive sampling technique to select 28 teachers and learners who taught and learnt Geography. The findings revealed that Geography teachers' decision to integrate ICT into their lessons was solely based on the availability of ICT facilities. Again, the school administration played a significant role in fostering teachers' and learners' use of ICT, because the administration was accountable in the school for maintaining and providing these ICT tools. Consequently, the failure to maintain properly and the absence of suitable ICT resources has adversely hampered the integration of ICTs into geographical education.

\section{Methodology}

\subsection{Research design}

The descriptive survey research design was used to achieve the research objectives and solve the research issue. According to Gray (2004), a descriptive survey endeavors to gather data from a population sample to assess the existing situation of the population regarding one or more issues. The significance of a descriptive survey to educational study cannot be overstated (Fraenkel \& Wallen, 2003). These researchers come to the conclusion that using a descriptive survey method allows a researcher to obtain a useful understanding of the existing state of a phenomenon in relation to causes or situations. According to Sincich (1993), descriptive surveys are useful for analyzing a variety of educational issues such as perceptions, demographic data, attitudes, practices, and circumstances. This implies that descriptive data is often gathered by questionnaire distribution, interviews, or observations.

\subsection{Population and sampling technique}

The study's participants were all Social Studies teachers from the New Juaben Municipality's public Senior High Schools (SHS) as indicated in Table 1. These schools are Oyoko Methodist SHS, Pope John SHS, Ghana SHS, S.D.A SHS, Koforidua Technical Institute, Pentecost SHS, Koforidua Senior High Technical School, New Juaben SHS and Oti Boateng SHS. In all the nine public Senior High Schools, the Social Studies teachers were one hundred and seven (107).

The study was a census and, therefore, the entire population, both teachers and the public Senior High Schools were used for the study. This is in agreement with Cohen et al. (2004) who proposed that for a population size of 107 , the entire population can be used as a sample size for a survey study. Purposive sampling was utilized to select the subjects for the study. This refers to the sampling technique where a particular group is expressly selected with a definite purpose based on the evidence available. In this technique, the researchers purposively selected the subjects who were relevant for the study. The important criterion of the choice was the knowledge of the respondents about the problem under investigation and hence their suitability for the study.

The respondents' characteristics consisted of 45 (42.1\%) female teachers and 62 (57.9\%) male teachers. Twentythree percent were between 20 and 29 years, 51\% were between 30 and 39 years while $25 \%$ were 40 years and above. Nearly half (49.5\%) of the respondents reported having 6 to 10 years teaching Social Studies, 28\% reported having over 10 years of experience and $22.4 \%$ having 1 to 5 years teaching experience. In terms of ICT training received at school, 
most of the teachers $(64.5 \%)$ claimed to have received training in ICT with $35.5 \%$ not having received training.

Table 1. Population for the study and background variables of respondents

\begin{tabular}{|c|c|c|c|c|c|}
\hline \multicolumn{3}{|c|}{ Name of schools } & \multicolumn{3}{|c|}{ Number of Social Studies teachers } \\
\hline \multicolumn{3}{|c|}{ Oyoko Methodist Senior High Schools } & \multicolumn{3}{|c|}{14} \\
\hline \multicolumn{3}{|c|}{ Pope John Senior High Schools } & \multicolumn{3}{|c|}{12} \\
\hline \multicolumn{3}{|c|}{ S.D.A Senior High Schools } & \multicolumn{3}{|c|}{10} \\
\hline \multicolumn{3}{|c|}{ Pentecost Senior High Schools } & \multicolumn{3}{|c|}{10} \\
\hline \multicolumn{3}{|c|}{ Oti Boateng Senior High Schools } & \multicolumn{3}{|c|}{13} \\
\hline \multicolumn{3}{|c|}{ Koforidua Senior High Technical School } & \multicolumn{3}{|c|}{12} \\
\hline \multicolumn{3}{|c|}{ New Juaben Senior High Schools } & \multicolumn{3}{|c|}{13} \\
\hline \multicolumn{3}{|c|}{ Koforidua Technical Institute } & \multicolumn{3}{|c|}{10} \\
\hline \multicolumn{3}{|c|}{ Ghana Senior High Schools } & \multicolumn{3}{|c|}{13} \\
\hline \multicolumn{3}{|c|}{ Total } & \multicolumn{3}{|c|}{107} \\
\hline Gender & Freq. & $\%$ & Age (years) & Freq. & $\%$ \\
\hline Female & 45 & 42.1 & $20-29$ & 25 & 23.4 \\
\hline \multirow[t]{2}{*}{ Male } & 62 & 57.9 & $30-39$ & 55 & 51.4 \\
\hline & & & $40 \&$ above & 27 & 25.2 \\
\hline Qualification & Freq. & $\%$ & Years of Teaching Social Studies & Freq. & $\%$ \\
\hline Diploma & 8 & 7.5 & $1-5$ years & 24 & 22.4 \\
\hline B.Ed & 66 & 61.7 & $6-10$ years & 53 & 49.5 \\
\hline B.A/BSc & 29 & 27.1 & $11 \&$ above years & 30 & 28.0 \\
\hline Masters & 4 & 3.7 & & & \\
\hline Received ICT training & Freq. & $\%$ & & & \\
\hline Yes & 38 & 35.5 & & & \\
\hline No & 69 & 64.5 & & & \\
\hline
\end{tabular}

\subsection{Research instrument}

A questionnaire was employed for the study. It was used to gather quantitative data. A questionnaire can be defined as "An instrument for gathering self-report information from respondents through self-administration of question in a paper-and-pencil format" (p. 729) (Polit \& Beck, 2004). Structured questionnaires improve objectivity and facilitate statistical analysis. Respondents are asked to answer a set of questions that the researcher has formulated ahead of time.

To collect the data, questionnaire items were adapted from Acquah-Doughan (2015) and utilized as the research 
instrument. The Acquah-Doughan (2015) questionnaire has 36 items divided into four categories: availability of ICT facilities (10 items), use of ICT facilities (8 items), perception of ICT (10 items), and factors influencing ICT use (8 items). In this study, 20 items namely from Availability (10 items) and Perceptions (10 items) were adapted and used for the study.

The questionnaire was divided into three (3) parts. Section 'A' included items intended to obtain information on the demographic characteristics of respondents. Section 'B' was intended to elicit information about social studies teachers' perception toward the use of ICT in the teaching and learning of social studies, while section ' $\mathrm{C}$ ' inquired about the availability of ICT facilities in the teaching and learning of social studies at S.H.S. Items on a four-point Likert style questionnaire were created to accurately represent information. For assessing attitudes and perceptions, the Likert scale has been proven to be the most appropriate tool. This is because it lets respondents express their level of support for a cause with a list of statements about how they feel or think about it (Bryman, 2004). The Likert scale was the preferred instrument because its organization, administration, and scoring are easy (Borg \& Gall, 1983). The questionnaire was used because, in comparison to other methods, it offers the following benefits: a high response rate and ease of data processing. Its disadvantage is that respondents could be unable to respond appropriately to the structured items.

\subsection{Validity and reliability of the instrument}

A pilot test of the questionnaire instrument was performed in the Ofori Panin Senior High Schools and W.B.M Zion High School in the Abuakwa North Municipality in order to determine its validity, reliability, and appropriateness. This District was chosen as it shared a boundary with New Juaben Municipality and has similar characteristics to the study area. Brink (2001) defines reliability as the chance to get the same findings when a researcher measures numerous times the same variable or when more than one person measures the same variable. As a result, reliability is linked to the data collection instrument's measurement accuracy. If the calculation of the attribute under investigation correctly represents the true score, the instrument is said to be reliable (Polit \& Beck, 2004). Various authors have addressed the importance of pre-testing. According to Bryman (2004), pretesting "ensures that the instrument as a whole functions well" (p. 159). In agreement, Cohen et al. (2004) stated that "the researcher, to select appropriate levels for which to test the independent variables in order for differences to be observed and to identify possible snags in connection with any aspect of the investigation" (p. 215-216). Following these principles, respondents from these two Public Senior High Schools were used for the Pilot test. The pilot test results were of great help because they revealed flaws in the wording of a few of the questions that might have corrupted the responses. Responses to some of the questionnaire's items, as well as feedback from teachers, assisted in identifying items that were vague. This made it possible for the researcher to reach the final items that were used for this study.

The questionnaire's reliability was assessed using the Cronbach's coefficient alpha, with an emphasis on internal accuracy. It is the most widely used statistic for assessing internal accuracy, and its results convey accurate data. It determines how well one item's output predicts the performance of other items in the same instrument (Brink, 2001).

Table 2. Cronbach's coefficient alpha

\begin{tabular}{ccc}
\hline Section & Cronbach's coefficient alpha & Number of items \\
\hline A (Perception) & 0.74 & 10 \\
B (Availability) & 0.86 & 10 \\
\hline
\end{tabular}

The Acquah-Doughan (2015) questionnaire has 36 items made up of availability of ICT facilities (10 items), use of ICT facilities ( 8 items), perception of ICT (10 items), and factors influencing ICT use (8 items). The Cronbach alpha coefficients for all parts were $0.74,0.86,0.81$, and 0.78 , respectively. In this study, 20 items namely from Availability (10 items) and Perceptions (10 items) were adapted and used for the study. The reliability coefficients of the sections of the questionnaire were calculated, and the table (Table 2) shows the Cronbach's coefficient alpha scores for the different 
sections of the instrument. In the Acquah-Doughan (2015) questionnaire, the reported values reported for Perception and Availability were 0.78 and 0.74 . This current study recorded 0.74 and 0.86 respectively for Perception and Availability.

\subsection{Data analysis}

The data was processed in three phases: first, the questionnaires were edited, then the answers were coded, and finally, the data was analyzed. After the questionnaires were retrieved, the editing stage included searching for inaccuracies to see whether any of the items had been answered. The data analysis stage was the third stage. The quantitative data were entered into the Statistical Product for Service Solution version 21 (SPSS spreadsheet) and analyzed using descriptive statistics (frequencies, percentages, mean, and standard deviation) and inferential statistics (t-test, ANOVA, correlation and regression).

\section{Results and discussions}

The findings and the discussion of the results are presented below. A total of 107 questionnaires were distributed to Social Studies teachers in the New Juaben Municipality (North and South), with a 100\% response rate. The 107 completed questionnaires were used in the analysis. The data was analyzed based on the research questions.

\subsection{Research question 1}

What are the perceptions of Social Studies teachers towards ICT integration into the teaching and learning of Social Studies in Senior High Schools in the New Juaben Municipality?

A four Likert scale ranging from 1 to 4 was used to rate the perception of Social Studies teachers towards ICT integration into the teaching and learning of Social Studies in senior high schools in the New Juaben Municipality as follows: 1-Strongly disagree, 2-Disagree, 3-Agree and 4-Strongly Agree. The following cut-off ranges were used to classify the teachers' perceptions as shown in the questionnaire responses: positive perception = mean value between 2.50 and 4 , and negative perception = mean value between 1.00 and 2.50. A standard deviation of more than 1.00 was considered indicative of considerable response variability.

Results from Table 3 indicate that all ten items have mean values above the critical value of 2.5. This means that the respondents possessed a positive perception of integration of ICT into Social Studies lessons. Out of a total of 107 respondents, $92(86.4 \%)$ of the respondents agreed that the integration of ICT in Social Studies classrooms makes the lesson more interesting while $15(13.6 \%)$ of the respondents disagreed. Also, $92(86.4 \%)$ agreed that ICT integration makes Social Studies lesson more diverse as 15(13.6\%) disagreed. In addition, 95 respondents $(88.8 \%)$ were in agreement with the view that ICT integration improves lesson presentation in the Social Studies classroom, whereas 12 respondents (11.2\%) disagreed. Results further reveal that majority of the respondents being $94(87.9 \%)$ agreed that incorporating ICT into Social Studies lessons motivates students in their learning, but 13 (2.1\%) disagreed.

More than three-quarters of the respondents (75.7\%) agreed that integrating ICT into Social Studies lessons, gives the teacher more confidence in teaching whilst $26(24.3 \%)$ disagreed. There were 86 respondents $(80.6 \%)$ who agreed that ICT integration in Social Studies lessons enables the teacher to manage instructional time very well, whereas $21(19.4 \%)$ disagreed. When asked about ICT integration increasing productivity in lesson preparation and lesson update, 94 respondents (88\%) agreed while $13(12 \%)$ disagreed. Further analysis from Table 3 portrays that 86 of the respondents (80.4\%) agreed that integrating ICT into Social Studies lessons helps students to understand what they have been taught, but 21 (19.6\%) disagreed.

On the issue of ICT integration in Social Studies lessons making students attentive in class, the majority of the respondents representing $78(72.9 \%)$ agreed while 29 (27.1\%) disagreed. With the issue of ICT making lessons more concrete and real for the learners, 77 (71.8\%) agreed while 30 (28.2\%) disagreed. 
Table 3. Perception of Social Studies teachers towards ICT integration in the teaching and learning of Social Studies

\begin{tabular}{|c|c|c|c|c|c|c|}
\hline Item & $\begin{array}{l}\text { Strongly } \\
\text { disagree } \\
\text { Freq. (\%) }\end{array}$ & $\begin{array}{l}\text { Disagree } \\
\text { Freq. (\%) }\end{array}$ & $\begin{array}{l}\text { Agree } \\
\text { Freq. (\%) }\end{array}$ & $\begin{array}{l}\text { Strongly } \\
\text { agree } \\
\text { Freq. (\%) }\end{array}$ & M & Std. D \\
\hline Make lessons more interesting & $9(8.0)$ & $6(5.6)$ & $80(75.0)$ & $12(11.4)$ & 2.89 & 0.71 \\
\hline Make lessons more diverse & $3(2.8)$ & $12(11.4)$ & $55(51.4)$ & $37(34.4)$ & 3.17 & 0.73 \\
\hline Improves lesson presentation & $7(6.5)$ & $5(4.7)$ & $81(75.7)$ & $14(13.1)$ & 2.93 & 0.69 \\
\hline Motivate students in their learning & $6(5.6)$ & $7(6.5)$ & $45(42.1)$ & $49(45.8)$ & 3.28 & 0.82 \\
\hline $\begin{array}{l}\text { Gives the teacher more } \\
\text { confidence in teaching }\end{array}$ & $5(4.7)$ & $21(19.6)$ & $67(62.6)$ & $14(13.1)$ & 2.84 & 0.70 \\
\hline $\begin{array}{l}\text { Enable the teacher to manage } \\
\text { instructional time very well }\end{array}$ & $9(8.0)$ & $12(11.4)$ & $77(72.6)$ & $9(8.0)$ & 2.80 & 0.71 \\
\hline $\begin{array}{l}\text { Increase productivity in lesson } \\
\text { preparation and lesson update }\end{array}$ & $9(8.0)$ & $4(4.0)$ & $62(58)$ & $32(30)$ & 3.09 & 0.82 \\
\hline $\begin{array}{l}\text { Help students to understand } \\
\text { what they have been taught }\end{array}$ & $10(9.3)$ & $11(10.3)$ & $66(61.7)$ & $20(18.7)$ & 2.90 & 0.81 \\
\hline Makes students attentive in class & $11(10.3)$ & $18(16.8)$ & $78(72.9)$ & - & 2.63 & 0.67 \\
\hline Makes lessons more concrete in class & $12(11.4)$ & $18(16.8)$ & $55(51.4)$ & $22(20.4)$ & 2.81 & 0.89 \\
\hline
\end{tabular}

Decision mean $=2.5$; overall mean $=2.93$

From the analysis of the data as depicted in Table 3, one could infer that the teachers had positive perceptions of integrating ICT into the teaching and learning of Social Studies. This is in line with previous studies such as Hong (2016), Mahdum et al. (2019), Padmavathi (2013), and Semerci and Aydin (2018) where similar findings were found with teachers had positive attitudes about the use of ICT in classrooms. Teachers play an important role in ICT integration since the usage of ICT in the classroom is dependent on teachers' attitudes about the concept (Hong, 2016). To put it another way, to successfully integrate ICT, teachers must have a positive mindset. The implication of this finding is that the teachers will readily adopt ICT into the teaching and learning giving the necessary training and resources. Furthermore, the findings also revealed that the perception of teachers on ICT integration in Social Studies is numerous. A large percentage of respondents agreed that ICT arouses the interest of the learners during the teaching and learning process. This confirms a study conducted by Haddad and Drexler (2002). They discovered that incorporating ICT into teaching and learning boosts academic curiosity and provides a sense of pleasure, causing students to move from passive recipients of knowledge to active producers of information.

These results support Perrotta's (2013) assertion that the perceived advantages of using technology include access to a broader range of learning material and tools, as well as the ability for students to become more inspired, involved and autonomous, and responsive in their learning process. Moreover, these findings corroborated Slouti and Barton's (2007) assertion that ICT would inspire students in their learning by supporting diversity in learning in the classroom while also maintaining teachers' interest in teaching. According to Balanskat et al., (2007), using ICT allows teachers to use less time and improve efficiency in tasks such as planning and reviewing regular lessons and keeping records. The study backs up Lai and Pratt's (2004) findings, which revealed that teachers thought ICT was beneficial to their instruction but not in terms of delivery methods or classroom practice. Rather than a shift in theory or pedagogy, teachers saw enhanced proficiency in the management of teaching, including class planning and presentation.

From the above, it is important to note the teachers' positive perception of integration of ICT and its benefits in the teaching and learning of Social Studies is the beginning of any successful integration of ICT in Social Studies classrooms. 


\subsection{Research question 2}

What ICT tools are available in the senior high schools in the New Juaben Municipality used in teaching and learning Social Studies?

The research question's main goal was to see whether there were any ICT resources for Social Studies instruction in Senior High Schools in the New Juaben Municipality. Data on responses to items on the available ICT resources used in teaching and learning Social Studies in senior high schools in the New Juaben Municipality were collected, collated, and analyzed using percentages in order to address this question. The frequency counts of the number of respondents who gave different responses were computed as a result of this. The results are indicated in Table 4.

Table 4. Available ICT tools used in teaching and learning of Social Studies

\begin{tabular}{ccccccc}
\hline Item & $\begin{array}{c}\text { Strongly } \\
\text { disagree } \\
\text { Freq. (\%) }\end{array}$ & $\begin{array}{c}\text { Disagree } \\
\text { Freq. (\%) }\end{array}$ & $\begin{array}{c}\text { Agree } \\
\text { Freq. (\%) }\end{array}$ & $\begin{array}{c}\text { Strongly } \\
\text { agree } \\
\text { Freq. (\%) }\end{array}$ & M & Std. D \\
\hline Computers & $56(52.3)$ & $28(26.2)$ & $9(8.0)$ & $14(13.5)$ & 1.82 & 1.1 \\
Internet systems e.g., Wi-Fi & $74(69.2)$ & $20(18.7)$ & $7(6.5)$ & $6(5.5)$ & 1.49 & 0.85 \\
Televisions & $66(61.7)$ & $18(16.9)$ & $16(14.9)$ & $7(6.5)$ & 1.66 & 0.96 \\
Photocopier & $45(42.1)$ & $50(46.7)$ & $8(7.5)$ & $4(3.7)$ & 1.73 & 0.76 \\
$\begin{array}{c}\text { Educational software for } \\
\text { teaching Social Studies }\end{array}$ & $72(67.3)$ & $20(18.7)$ & $8(7.5)$ & $7(6.5)$ & 1.53 & 0.89 \\
Overhead projectors & $67(62.7)$ & $20(18.7)$ & $13(12.1)$ & $7(6.5)$ & 1.63 & 0.94 \\
Printers & $76(71.0)$ & $17(15.9)$ & $8(7.5)$ & $6(5.6)$ & 1.48 & 0.86 \\
Digital video recorder & $19(17.9)$ & $69(64.8)$ & $10(9.3)$ & $9(8.0)$ & 2.08 & 0.78 \\
Android phones & $24(22.4)$ & $64(59.8)$ & $2(1.9)$ & $17(15.9)$ & 2.11 & 0.93 \\
Digital cameras & $22(20.6)$ & $66(7.3)$ & $12(11.2)$ & $7(6.5)$ & 2.04 & 0.76 \\
\hline
\end{tabular}

Decision mean $=2.5$; overall mean $=1.76$

From Table 4, it can be seen that on the issue of the availability of ICT tools for the teaching and learning of social studies, per the mean values the respondents disagreed on the availability of all the ten ICT resources. Generally, the respondents expressed a negative perception of the availability of ICT tools and resources for the teaching and learning of social studies. On the issue of the availability of computers for teaching Social Studies, most of the respondents 84 (78.5\%) disagreed whereas $23(21.5 \%)$ agreed. Further analysis revealed that $94(87.9 \%)$ disagreed with the availability of internet systems in teaching Social Studies while 13 (12.1\%) agreed. Another issue was the availability of televisions in support of teaching Social Studies. The majority of the respondents, 84 (78.6\%) disagreed whereas $23(21.4 \%)$ agreed.

On the issue of the availability of photocopier machines for printing materials to support students learning, 95 $(88.8 \%)$ of the respondents disagreed while $12(11.2 \%)$ agreed. In response to the statement: availability of educational software for teaching Social Studies, more than two-thirds of the respondents $92(86.0 \%)$ disagreed while 15 (14.0\%) agreed to the statement. Results from Table 4 further revealed that out of the total of 107 respondents selected for the study, $87(81.3 \%)$ disagreed with the availability of overhead projectors for teaching Social Studies, while 20 (18.7\%) agreed. $93(86.9 \%)$ disagreed with the availability of printers to support the teaching and learning of Social Studies while a minority of them 14 (13.1\%) agreed. Further analysis from Table 4 indicated that $88(82.7 \%)$ of the respondents disagreed on the issue of the availability of a digital video recorder as a facility in teaching Social Studies while 19 $(17.3 \%)$ disagreed. Most respondents, constituting $88(82.7 \%)$ disagreed with the availability of android phones as 
a facility in teaching Social Studies while 19 (17.3\%) agreed. It is obvious from the analysis that the majority of the respondents representing $88(82.7 \%)$ disagreed with the availability of digital cameras to support the teaching and learning of Social Studies.

A look at Table 4 reveals that the majority of the respondents are of the view that there are inadequate computers in the schools. According to Adebi-Caesar (2012), 69 (97.9\%) of teachers reported having inadequate computers and equipment, while only 2.1 percent said they had adequate computers. When asked if they do use computers at school, 90.7 percent said they never do, while 9.3 percent said they do. This clearly demonstrates that many of the schools studied lack sufficient enough computers for Social Studies lessons. It is evident from Table 4 that most of the schools do not have internet facilities to support the learning and teaching of Social Studies. In contrast, Ayebi-Arthur et al. (2009) found that the majority of senior high teachers in the Cape Coast Metropolis have internet access. Also, 70 percent of the students had internet access. This demonstrates that the vast majority of students and teachers have internet access.

The majority of the respondents (78.6\%) disagreed with the availability and the use of television in teaching Social Studies. This attested to the fact that most of the schools do not use televisions as an aid in teaching Social Studies. The majority of the respondents disagreed with the availability of ICT facilities such as photocopiers, educational software, overhead projectors, printers, digital video recorder and digital cameras for teaching Social Studies. This is contrary to a study conducted by Ocak and Akdemir (2008) in Turkey. Implicitly the conclusion to be drawn from this study is that whiles the teachers possessed a positive view of the integration of ICT into teaching and learning of Social Studies, this positive view may likely be hampered due to the non-availability of ICT tools and resources.

\subsection{Research question 3}

Are there any significant differences between teachers' background characteristics (gender, age, academic qualification, teaching experience and training in ICT) and perceptions of integration of ICT into teaching and learning of Social Studies?

A one-way Analysis of Variance (ANOVA) and the T-test were used to assess whether there were significant differences in teachers' background variables and their perception of integration of ICT into the teaching and learning of social studies. The summary of the findings of a t-test analysis to see if there were any significant differences in perception of integration of ICT based on gender and training in ICT as independent variables are shown in Table 5. Significant differences were found for gender and perception of integration of ICT into teaching and learning of social studies. Female teachers have higher mean scores than male teachers. This implies that female teachers are more likely to hold positive perceptions and hence integrate ICT into their teaching. However, there were no significant differences between the perception of integration of ICT and training in ICT.

Additional one-way ANOVA analyses were performed to determine whether there were significant differences in teachers' perception of integration of ICT into teaching and learning of social studies according to age group, number of years in teaching social studies and academic qualification. As shown in Table 6, there were statistically significant differences among the age groups for perception $(\mathrm{F}(2,106)=10.563, \mathrm{p}<0.00)$, and for teaching experience in social studies, $(\mathrm{F}(2,106)=4.563, \mathrm{p}<0.05)$. In order to determine where the difference in perception lies, Scheffe's post hoc analysis was performed. The results showed that there were statistically significant differences in the perception of teachers aged 40 years and over (old) and 20-29 years (young) and between participants aged 40 years and above years (old) and 30-39 years (medium). Younger $(\mathrm{M}=3.06, \mathrm{SD}=0.53)$ and medium $(\mathrm{M}=3.04, \mathrm{SD}=0.25)$ aged teachers have a significant mean score than older $(\mathrm{M}=2.60, \mathrm{SD}=0.62)$ teachers. Thus, the younger the teacher the more likely to hold positive perceptions and integrate ICT into the teaching and learning of Social Studies.

Furthermore, a number of years of teaching experience in social studies, statistically significant differences were found between teachers with 5 to 10 years and 11 and above years. Teachers with less experience were more likely to hold a positive perception of integrating ICT into teaching and learning of social studies. However, there were no significant differences between academic qualification and perception of integration of ICT in the teaching and learning of social studies.

The findings of this study support Mahdum et al. (2019) study which discovered that ICT training and teacher perceptions have no statistically significant link, but contrary to Padmavathi (2013) where teachers' attitudes on computer use were unaffected by their age and gender. 
Table 5. Perceptions of ICT integration and T-test of differences in some independent variables

\begin{tabular}{cccccc}
\hline Variable & & $\mathrm{N}$ & Mean & SD & sig. \\
\hline Gender & Female & 45 & 2.96 & 0.35 & 0.510 \\
$\begin{array}{c}\text { Received training } \\
\text { in ICT }\end{array}$ & Male & 62 & 2.91 & 0.55 & $0.013^{*}$ \\
& Yes & 38 & 2.89 & 0.41 & -0.736 \\
\hline
\end{tabular}

* Significance level 0.05

Table 6. Perceptions of integration of ICT and analysis of variance in some independent variables

\begin{tabular}{|c|c|c|c|c|c|c|}
\hline & & Sum of squares & $\mathrm{df}$ & Mean square & $\mathrm{F}$ & Sig. \\
\hline \multicolumn{7}{|c|}{ Age } \\
\hline \multirow{3}{*}{ Age group } & Between groups & 4.052 & 2 & 2.026 & 10.563 & $0.000 * *$ \\
\hline & Within groups & 19.950 & 104 & 0.192 & & \\
\hline & Total & 24.950 & 106 & & & \\
\hline \multirow{3}{*}{$\begin{array}{l}\text { Academic } \\
\text { qualification }\end{array}$} & Between groups & 0.692 & 3 & 0.231 & 1.019 & 0.387 \\
\hline & Within groups & 23.310 & 103 & 0.226 & & \\
\hline & Total & 24.002 & 106 & & & \\
\hline \multirow{3}{*}{$\begin{array}{l}\text { Teaching } \\
\text { experience in } \\
\text { Social Studies }\end{array}$} & Between groups & 1.936 & 2 & 0.966 & 4.563 & $0.013^{*}$ \\
\hline & Within groups & 22.066 & 104 & 0.212 & & \\
\hline & Total & 24.002 & 106 & & & \\
\hline
\end{tabular}

** Significance level $0.01, *$ Significance level 0.05

\subsection{Research question 4}

What is the impact of the background characteristics of teachers on perceptions of ICT integration in teaching and learning of Social Studies?

Correlation and multiple regression analyses were performed to address this research question. This is to determine the impact of background characteristics of teachers on the perception of integration of ICT into the teaching and learning of social studies. The findings are presented in Tables 7 and 8 . The results in Table 7 indicate that age was negatively correlated with the perception of ICT integration in teaching and learning of Social Studies. This implies that the younger the age of the teacher, the more likely he/she holds a positive perception of ICT integration into teaching and learning of Social Studies. Gender, academic qualification, training in ICT and teaching experience show no relationship with perception of integration of ICT in the teaching and learning of Social Studies. This suggests that teachers' gender, teaching experience, qualification and training in ICT have nothing to do with the perceptions of ICT integration.

Table 8 shows the results of multiple regression analysis. The five independent variables were gender, age, academic qualification, teaching experience and marital training in ICT. The results indicate that the five background characteristics variables of the students explained $9 \%$ of the variance of perception of ICT integration $(\mathrm{R}=0.37$ and adjusted $\mathrm{R}$ square $=0.09)$. The impact was significant $(\mathrm{F}(5,106)=3.17, \mathrm{p}<0.05)$. Except for age, all of the other 
background variables included in the regression were not predictors of perception of integration of ICT in teaching and learning of Social Studies. In the analysis, age $(\beta=-0.35, \mathrm{t}=-3.67, \mathrm{p} \leq 0.00$ was identified as a significantly negative predictor of the perception of integration of ICT into teaching and learning of Social Studies.

Table 7. Correlations between demographic characteristics and perception of ICT integration $(\mathrm{N}=107)$

\begin{tabular}{|c|c|c|c|c|c|c|}
\hline & 1 & 2 & 3 & 4 & 5 & 6 \\
\hline Gender & 1 & & & & & \\
\hline Age & 0.06 & 1 & & & & \\
\hline Qualification & -0.06 & -0.16 & 1 & & & \\
\hline Experience & -0.09 & -0.06 & -0.05 & 1 & & \\
\hline ICT training & $0.36^{* *}$ & $-0.20^{*}$ & $0.28^{\text {*** }}$ & $0.20^{* *}$ & 1 & \\
\hline Perception of ICT integration & 0.05 & $-0.35^{* *}$ & 0.12 & -0.05 & 0.07 & 1 \\
\hline
\end{tabular}

** Correlation is significant at the 0.01 level (2-tailed), * Significant at the 0.05 level

Table 8. Multiple regression analysis of five independent variables on the dependent variable

\begin{tabular}{|c|c|c|c|c|c|}
\hline \multicolumn{6}{|c|}{ Model summary } \\
\hline & $\mathrm{R}$ & $\mathrm{R}$ square & Adjusted R square & & \\
\hline \multirow[t]{2}{*}{ ANOVA (b) } & 0.35 & 0.14 & 0.09 & & \\
\hline & Sum of squares & df & Mean square & $\mathrm{F}$ & Sig. \\
\hline Regression & 3.355 & 5 & 0.65 & 3.17 & 0.011 \\
\hline Residual & 20.747 & 101 & 0.21 & & \\
\hline \multirow[t]{3}{*}{$\begin{array}{c}\text { Total } \\
\text { coefficients (a) }\end{array}$} & 24.002 & 106 & & & \\
\hline & \multicolumn{2}{|c|}{ Unstandardized coefficients } & Standardized coefficients & $\mathrm{t}$ & Sig. \\
\hline & $\mathrm{B}$ & Std. Error & Beta & & \\
\hline (Constant) & 3.300 & 0.31 & & 10.786 & 0.00 \\
\hline Academic level & 0.084 & 0.10 & 0.09 & 0.847 & 0.40 \\
\hline Sex & -0.239 & 0.07 & -0.35 & -3.673 & $0.00 * *$ \\
\hline Religion & 0.060 & 0.07 & 0.08 & .832 & 0.41 \\
\hline Age & -0.031 & 0.07 & -0.05 & -0.479 & 0.63 \\
\hline Marital status & -0.046 & 0.11 & -0.05 & -0.417 & 0.68 \\
\hline Dependent variable: & tion & & & & \\
\hline
\end{tabular}

** Significant at the 0.01 level (2-tailed)

The finding from Table 8 revealed age is a crucial determinant of teachers' perception of the integration of ICT 
in the teaching and learning of Social Studies. This finding is in tandem with Korte and Husing (2007) who found that younger instructors are less skeptical about the benefits of ICT in the classroom. According to Young (2000), younger, less experienced teachers use computers more than older teachers because they are more likely to be computer literate, have had more technologically rich teacher training, and are less likely to be bound by previous behaviors, attitudes, or beliefs. The conclusion to be drawn here is that younger teachers are more likely to possess positive perceptions of integrating ICT into teaching and learning hence more willing in adopting and using ICT in their classrooms.

Despite the fact that this study has limitations in terms of sample size and data collection (using simply a questionnaire), the findings add to ICT integration practice in Ghana. The study could serve as a motivator for teachers to become more prepared to employ ICT in their teaching and learning activities.

\section{Conclusions}

The following conclusions can be taken from the research. The results show teachers had a positive perception of integrating ICT into teaching and learning of Social Studies. These perceptions include incorporating ICT into the teaching and learning of Social Studies makes lessons more engaging, varied, and well-presented, as well as allowing the teacher to effectively control instructional time. It can also be concluded that incorporating ICT into the classroom aids students in comprehending what they have been taught, makes lessons more concrete, and increases student attention in class. It is clear from the findings that ICT tools like computers, internet systems, educational software, printers and overhead projectors were found to be limited in the schools. The results indicated that the major factors affecting teachers' perception of integrating ICT in the social studies classrooms are their gender, age, and years of teaching experience. However, qualification and training in ICT did not yield significant results. Furthermore, this research revealed that teachers' perception of ICT integration is greatly determined by age.

\section{Recommendations}

The following recommendations are made based on the study's results and conclusions:

1. Heads of schools in the New Juaben Municipality should encourage teachers to use ICT infrastructure appropriately in the Social Studies classrooms.

2. The Ministry of Education should set aside funds each year to retain, replace, and extend ICT infrastructure in schools.

3. The Ministry of Education should review the policy of the use of mobile phones in senior high schools to enable students to use mobile phone devices and applications in their lessons.

\section{Conflicts of interests}

The authors declare no competing financial interest.

\section{References}

Abdullahi, H. (2014). The role of ICT in teaching science education in schools. International Letters of Social and Humanistic Sciences, 19, 217-223. https://doi.org/10.18052/www.scipress.com/ILSHS.19.217

Acquah-Doughan, M. (2015). Availabilty and utilisation of information and communication technology facilities in teaching social studies in public senior high schools in Sekondi-Takoradi metropolis. Masters dissertation, University of Cape Coast.

Adebi-Caesar, T. E. (2012). Assessment of I.C.T situation in senior high schools, a case study in Lower Manya Krobo District. Unpublished master's thesis, Kwame Nkrumah University of Science and Technology, Kumasi.

Adubifa, O. A. (2001). Towards the Introduction and Application of Information and Communication Technologies in 
African Universities. Accra: Quality Printing \& Graphics.

Aggarwal, J. C. (2001). Teaching of Social Studies: A Practical Approach. New Delhi: Vikas Publishing.

Agyei, D. D., \& Voogt, J. (2011). ICT use in the teaching of mathematics: Implications for professional development of pre-service teachers in Ghana. Education and Information Technologies, 16(4), 423-439.

Akaadom, B. W. (2019). Investigating the benefits of incorporating technology in instructional curriculum: Pre-service teachers' perspectives from Ghana. International Journal of Innovative Research and Advanced Studies, 6(2), 3947.

Al-Senaidi, S., Lin, L., \& Poirot, J. (2009). Barriers to adopting technology for teaching and learning in Oman. Computers \& Education, 53(3), 575-590. https://doi.org/10.1016/j.compedu.2009.03.015

Amengor, J. (2011). History teachers' perception of ICT in promoting teaching and learning. Unpublished master's thesis, History Department, University of Cape Coast, Cape Coast.

Anderson, R. E., \& Becker, H. J. (2001). School investments in instructional technology: Report\#8 of the teaching, learning, and computing project. Irvine: Center for Research on Information Technology and Organizations, University of California, Irvine.

Ayebi-Arthur, K., Aidoo, D. A., \& Wilson, K. B. (2009). A study on the use of the Internet in senior high schools in the Cape Coast metropolis of Ghana. Ghana Journal of Education and Teaching, 5, 131-141.

Balanskat, A., Blamire, R., \& Kafal, S. (2007). A review of studies of ICT impact on schools in Europe. European School net.

Bariham, I., Ayot, H. O., Ondigo, S. R., Kiio, M. N., \& Nyamemba, N. P. (2019). An assessment of basic school teachers' integration of computer-based instruction into social studies teaching in West Mamprusi Municipality; Implications for further development of computer-based instruction use in Ghanaian schools. International Journal of Research and Innovation in Social Science, 3(5), 72-82.

Becker, H. J. (1994). How exemplary computer-using teachers differ from other teachers: Implications for realizing the potential of computers in schools. Journal of Research on Computing in Education, 26(3), 291-321. https://doi.org/ $10.1080 / 08886504.1994 .10782093$

Berson, M. J. (1996). Effectiveness of computer technology in the Social Studies: A review of the literature. Journal of Research on Computing in Education, 28(4), 486-499. https://doi.org/10.1080/08886504.1996.10782179

Bingimlas, K. A. (2009). Barriers to the successful integration of ICT in teaching and learning environments: A review of the literature. Eurasia Journal of Mathematics, Science and Technology Education, 5(3), 235-245. https://doi. org/10.12973/ejmste/75275

Boakye, K. B., \& Banini, D. A. (2008). Teacher ICT readiness in Ghana. In K. Toure, T., Tchombe, S., \& Karsenti, T. (Eds.), ICT and Changing Minds in Education. Bamenda, Cameroun; Langaa; Bamako, Mali: ERNWACA/ ROCARE.

Bolick, C. M., Berson, M. J., Friedman, A. M., \& Porfeli, E. J. (2007). Diffusion of technology innovation in the pre service Social Studies experience: Results of a national survey. Theory \& Research in Social Education, 35(2), 174-195. https://doi.org/10.1080/00933104.2007.10473332

Bordoh, A.; Eshun, I.; Kwarteng, P.; Osman, S.; Brew, E.; Bakar, A. (2018). Professional qualification of teachers in teaching and learning of social studies concepts in the senior high schools in Ghana. American Journal of Social Sciences, 6(2), 25-28.

Borg, W. R., \& Gall, M. D. (1983). Educational Research: An Introduction (4th ed.). New York: Longman.

Brink, P. J. (2001). Representing the population in qualitative research. Western Journal of Nursing Research, 23(7), 661-663. https://doi.org/10.1177/01939450122045465

British Educational Communications and Technology Agency (Becta) (2004). A review of the research literature on barriers to the uptake of ICT by teachers. https://dera.ioe.ac.uk/1603/1/becta_2004_barrierstouptake_litrev.pdf

Bryman, A. (2004). Social Research Methods (2nd ed.). Oxford: Oxford University Press.

Buabeng-Andoh, C. (2012). Factors influencing teachers' adoption and integration of information and communication technology into teaching: A review of the literature. International Journal of Education and Development using Information and Communication Technology (IJEDICT), 8(1), 136-155.

Cavas, B., Cavas, P., Karaoglan, B. \& Kisla, T. (2009). A study on science teachers' attitudes toward Information and Communication Technologies in education. The Turkish Online Journal of Educational Technology, 8(2), 20-32.

Chirwa, C. \& Mubita, K. (2021). Preparedness of teachers and learners in the integration of information communication technologies in the teaching and learning of geography in selected schools of Petauke District of Eastern Province in Zambia. International Journal of Research and Innovation in Social Science, 5(3), 456-464.

Cohen, L., Manion, L. \& Morrison, K. (2004). Research Methods in Education. (7th ed.). London: Routledge. 
Condie, R., \& Munro, R. K. (2007). TheImpact of ICT in Schools-a Landscape Review. Glasgow.

Dawes, L. (2001). Chalky and the Interactive Whiteboard: media representation of teachers and technology. Paper Presented to the British Educational Research Association, London.

Dawson, C., \& Rakes, G. C. (2003). The influence of Principals' technology training on the integration of technology into schools. Journal of Research on Technology in Education, 36(1), 29-49. https://doi.org/10.1080/15391523.200 3.10782401

Dede, C. (1998). Learning about teaching and vice versa. Paper presented at conference of Society for Information Technology in Education, Washington D.C., USA.

Drent, M., \& Meelissen, M. (2008). Which factors obstruct or stimulate teacher educators to use ICT innovatively. Computers and Education, 51, 187-199. https://doi.org/10.1016/j.compedu.2007.05.001

Ehman, L. H., \& Glenn, A. D. (1991). Interactive technologies in the Social Studies. In J. P. Shaver (Ed.), Handbook of research on Social Studies teaching and learning (pp. 513-522). New York, NY: McMillan Publishing Company.

Eugene, J. (2006). How teachers integrate technology and their beliefs about learning: Is there a connection? Journal of Technology and Teacher Education, 14(3), 581-597.

Fan, C. W. \& Ho, K. K. (2012). A tale of three cities: Review of the development of ICT in school education between Hong Kong, Macau and Singapore. New Horizons in Education, 60(1), 70-82.

Forcheri, P., \& Molfino, M. T. (2000). ICT as a tool for learning to learn. In D. M. Watson, \& T. Downes (Eds.), Communications and networking in Education (pp. 175-184). Boston, MA: Kluwer Academic.

Fraenkel, J. R. \& Wallen, N. E. (2003). How to Design and Evaluate Research in Education (5th ed.). Boston: McGrawHill.

Ghavifekr, S., Afshari, M., \& Amla Salleh. (2012). Management strategies for E-Learning system as the core component of systemic change: A qualitative analysis. Life Science Journal, 9(3), 2190-2196.

Government of Ghana (2003). The Ghana ICT for accelerated development (ICT4AD) policy Accra: Authur.

Government of Ghana (2004). Meeting the challenges of education in the $21^{\text {st }}$ century. Accra: Adwinsa publications.

Grabe, M., \& Grabe, C. (2007). Integrating Technology for Meaningful Learning (5th ed.). Boston, MA: Houghton Mifflin.

Gragert, E. (2000). Expanding international education through the Internet: No longer limited to the global studies and language curriculum. Washington, DC: White Paper prepared for the Secretary of Education's Conference on Technology in Education.

Gray, D. E. (2004). Doing Research in the Real World. London: SAGE.

Gulbahar, Y., \& Guven, I. (2008). A survey on ICT usage and the perceptions of social studies teachers in Turkey. Educational Technology \& Society, 11(3), 37-51.

Haddad, W. D. \& Drexler, A. (2002). Technologies for education. Paris: UNESCO and the Academy for Educational Development.

Harris, J. M. (2000). Utilization of computer technology by teachers at Carl Schurz High School, a Chicago public school (Illinois). Doctor of Education thesis, Northern Illinois University. https://www.learntechlib.org/p/116133/

Hawkins, R. J. (2002). Ten lessons for ICT and Education in the developing World. In S. Dutta, B. Lanvin, \& F. Paua, (Eds.), Global information technology report (20042005). World Economic Forum: Oxford University Press.

Hennessy, S. Ruthven, K., \& Brindley, S. (2005). Teacher perspectives on integrating ICT into subject teaching: Commitment, Constraints, Caution, and Change. Journal of curriculum studies, 37, 155-192. https://doi. org/10.1080/0022027032000276961

Hong, J. E. (2014). Promoting teacher adoption of GIS using teacher-centered and teacher friendly design. Journal of Geography, 113(4), 139-150. https://doi.org/10.1080/00221341.2013.872171

Hong, J., E. (2016, April 30). Social Studies Teachers' Views of ICT Integration. Review of International Geographical Education Online, 6(1), 32-48.

Huang, H. M., \& Liaw, S. S. (2005). Exploring users' attitudes and intentions toward the web as a survey tool. Computers in Human Behaviour, 21(5), 729-743.

Jacobson, M., \& Levin, J. (1993). Conceptual frameworks for network learning environments: Constructing personal and shared knowledge spaces. Location of publishers: University of Illinois at Urbana Champaign and Vanderbilt University.

Jamieson-Proctor, R. M., Burnett, P. C, Finger, G., \& Watson, G. (2006). ICT integration and teachers' confidence in using ICT for teaching and learning in Queensland state schools. Australasian Journal of Educational technology, 22(4), 511-530.

Jorge, C. M. H., Jorge M. C. A., Gutiérrez, E. R., García, E.G., \& Díaz, M. B. (2003). Use of the ICTs and the 
perception of e-learning among university students: A differential perspective according to gender and degree year group. Interactive Educational Multimedia, 7, 13-28.

Korte, W. B. \& Husing, T. (2007). Benchmarking Access and Use of ICT in European Schools 2006: Results from Head Teacher and A Classroom Teacher Surveys in 27 European Countries. eLearning Papers, 2(1), 1-6.

Kumar, N., Rose, C. R. \& D’SIiva, J. L. (2008). Teachers' readiness to use technology in the classroom: An empirical study. European Journal of Scientific Research, 21(4), 603-616.

Lai, K. W., \& Pratt, K. (2004). Information Communication Technology (ICT) in secondary schools: The role of the computer coordinator. British Journal of Educational Technology, 35(4), 461-475.

Law, N., Lee, Y., \& Chow, A. (2002). Practice characteristics that lead to 21st century learning outcomes. Journal of Computer Assisted Learning, 18(4), 415-426. https://doi.org/10.1046/j.0266-4909.2002.00253.doc.x

Littlejohn, A., Suckling, C., Campbell, L., \& McNicol, D. (2002). The amazingly patient tutor: students' interactions with an online carbohydrate chemistry course. British Journal of Educational Technology, 33(3), 313-321.

Mahdum, M., Hadriana, H., \& Safriyanti, M. (2019). Exploring teacher perceptions and motivations to ICT use in learning activities in Indonesia. Journal of Information Technology Education: Research, 18, 293-317. https://doi. org/10.28945/4366

Martorella, P. (1985). Elementary Social Studies: Developing Reflective, Competent, and Concerned Citizens. Boston: Little Brown Blandford Press.

Martorella, P. (1997). Technology and the Social Studies: Which way to the sleeping giant? Theory and Research in Social Education, 25(4), 511-514.

Meyer, J. W., Butterick, J., Olkin, M., \& Zack, G. (1999). GIS in the K-12 Curriculum: A cautionary note. The Professional Geographer, 51(4), 571-578.

Mfum-Mensah, O. (2003). Impact of non-formal basic education programs: a case study of Northern Ghana Unpublished Ph.D. dissertation. University of Toronto.

Miima, F., Ondigi, S., \& Mavisi, R. (2013). Teachers' perception about integration of ICT in teaching and learning of Kiswahili language in secondary schools. International Journal of Arts and Commerce, 2(3), 27-32.

Ministry of Education (2008, November). ICT in Education Policy, Ghana. https://en.unesco.org/icted/sites/default/ files/2019-04/15_ict_in_education_policy_ghana.pdf

National Council for the Social Studies (1994). Curriculum standards for Social Studies: Expectations of excellence (Bulletin No. 89). Washington, DC: National Council for the Social Studies.

Ocak, M. A., \& Akdemir, O. (2008). An investigation of primary school science teachers' use of computer applications. The Turkish Online Journal of Educational Technology, 7(4), 610-617.

Osin, L. (1998). Computers in education in developing countries: Why and how? Education and Technology Series, 3(1), 1-14. https://citeseerx.ist.psu.edu/viewdoc/download?doi=10.1.1.194.4660\&rep=rep1\&type=pdf

Padmavathi, M. (2013). A survey of secondary school teachers' perceptions, competency and use of computers. International Journal of Education and Psychological Research, 2(4), 7-16.

Pelgrum. W. J., \& Law, N. (2001). ICT in education around the world: trends, problems and prospect. Marco Grafico: UNESCO.

Perrotta, C. (2013). Do school-level factors influence the educational benefits of digital technology? A critical analysis of teachers' perceptions. British Journal of Educational Technology, 44(2), 314-327.

Pittard, V., Bannister, P., \& Dunn, J. (2003). The big picture: The impact of ICT on attainment, Motivation and learning. London: DfES.

Polit, D. F., \& Beck, C. T. (2004). Nursing Research: Appraising Evidence for Nursing Practice (7th ed.). Philadelphia: Wolters Klower/Lippincott.

Rodríguez-Rodríguez, I., \& Heras-González, P. (2020). How are universities using Information and Communication Technologies to face sexual harassment and how can they improve? Technology in Society, 62, 101274. https://doi. org/10.1016/j.techsoc.2020.101274

Rozell, E. J., \& Gardner III, W. L. (1999). Computer-related success and failure: A longitudinal field study of the factors influencing computer-related performance. Computers in Human Behavior, 15(1), 1-10.

Schulz-Zander, R., Büchter, A., \& Dalmer, R. (2002). The role of ICT as a promoter of students' cooperation. Journal of Computer Assisted Learning, 18(4), 438-448.

Segers, E., \& Verhoeven, L. (2002). Multimedia support of early literacy learning. Computers \& Education, 39(3), $207-221$.

Semerci, A. \& Aydin, M.K. (2018). Examining High School Teachers' Attitudes towards ICT Use in Education. International Journal of Progressive Education, 14(2), 93-105. https://doi.org/10.29329/ijpe.2018.139.7

Sim, C. H., \& Lau, B. T. (2014). Teachers'perceptions of the use of ICT as an instructional tool in Mathematics and 
Science. New York, NY: Dellen.

Simonson, M. (2004). Technology use of Hispanic bilingual teachers: A function of their beliefs, attitudes and perceptions on peer technology use in the classroom. Journal of Instructional Technology, 31(3), 257-266.

Sincich, T. (1993). Statistics by Example (5th ed.). New York, NY: Dellen.

Slouti, D., \& Barton, A. (2007). Opportunities for practice and development: Newly qualified teachers and the use of information and communication technologies in teaching Foreign Language in English Secondary school Context. Journal of In-service Education, 33(4), 405-424. https://doi.org/10.1080/13674580701687807

Smeets, E. (2005). Does ICT contribute to powerful learning environments in primary Education? Computers and Education, 44(3), 343-355.

Stennes, B. (2008). Advantages and disadvantages of web-based learning. Coventry: BECTA.

Sugar, W., Crawley, F., \& Fine, B. (2004). Examining teachers' decisions to adopt new Technology. Educational Technology \& Society, 7(4), 201-213.

Tezci, E. (2009). Factors that influence pre service teachers' ICT usage in education. European Journal of Teacher Education, 34, 483-499.

Tomei, L. A. (2005). Taxonomy for the technology domain. USA: Information.

United Nation Development Programme (UNDP) (2006, January). Human Development Report. http://hdr.undp.org

UNESCO (2007). The UNESCO ICT in education programme. Bangkok: UNESCO.

Wheeler, S. (2001). Information and communication technologies and the changing role of the teacher. Journal of Educational Media, 26(1), 7-17.

World Bank (2012, December 20). Burundi Education Sector Reconstruction Project: Implementation Completion and Results Report. https://documents.worldbank.org/en/publication/documents-reports/documentdetail/645221468014430427/ burundi-education-sector-reconstruction-project

Yelland, N. (2001). Teaching and learning with information and communication technologies (ICT) for numeracy in the early childhood and primary years of schooling. Australia: Department of Education, Training and Youth Affairs.

Young, B. J. (2000). Gender differences in student attitudes toward computers. Journal of Research on Computing in Education, 33(2), 204-217.

Zhao, Y., \& Cziko, G. A. (2001). Teacher adoption of technology: A perceptual control theory perspective. Journal of Technology and Teacher Education, 9(1), 5-30. 